Is Demand for Polluting Goods Manageable?
This model displays immediate adjustment and a price elasticity for gasoline of -0.8. Demand for gasoline. and the subsequent generdion of pollution, are sensitive to pricing policies.

Gunnar S. Eskeland

Tarban N. Feyzioglu

The World Bank

Policy Research Department

Public Economics Division

June 1994 


\section{Summary findings}

Charging for social marginal costs is efficient regardless of price elasticities, but the importance of getting prices "right" is grearer the more manageable, or elastic, the demand. In efficient pollution control programs, options to make cars cleaner are combined optimally with demand conservation. The roles played by "cleaner cars" as compared with "fewer trips" are determined by empirical paramerers: cheap, clean technologies would imply a great role for cleaner cars, while high demand elasticities lead to a greater role for demand reduction.

In seminal research, Pindyck found evidence to. support his hypothesis that demand for commodities such as gasoline should have lower price elasticities and higher income elasticiries in developing than in industrial countries. Eskeland and Feyzioglu estimate a model of gasoline demand and car ownership in Mexico, using a panel of annual observations by state. Key features they introduce are instrumental variables on differenced data and the treatment of (1) possible dynamics, (2) measurement errors in the data, and (3) unobserved characteristics in individual states. They use tests of serial correlation in the residuals to model the dynamics properly. The resulting model is one of almost immediate adjustment, with a short-term price elasticity for gasoline close to the long-term estimate of -0.8 .

The model displays elasticities that are lower (for income) and higher (for price) than those Pindyck hypothesized; and are within the range of elasticities found in industrial councries.

Byproducts of the model: The elasticity of car purchases with respect to gasoline prices is positive. Scrappage decisions are affected by income and by car and gasoline prices. And these elasticities are not significantly different in the richer states.

For policy purposes, these findings do not stppors "elasticity pessimism." The use of car services is sensitive to pricing, which suggests that consumers, for some of their demand, have reasonably good alternatives to car services. Consideration of external costs - such as accidents, congestion, air pollution, and road damage thus involve considerable demand conservation.

This paper - a product of the Public Economics Division, Policy Research Department - is part of a larger effort in the department to sndy environmental policy problems in developing countries, emphasizing fiscal pelicy instruments. The study was funded by the Bank's Research Support Budget under the research project "Pollution and the Choice of Policy Instruments in Developing Countries" (RPO 676-48). Copies of this paper are available free from the World Bank, 1818 H Street NW, Washington, DC 20433. Please contact Carlina Jones, room N10-063, extension 37699 (31 pages).June 1994.

The Policy Research Working Paper Series disseminates the findings of work in progress to encourage the exchange of ideas about deselopment iscues Ar objective of the series is to get the findings out quickly, exen if the presentations are less than fully polished The papers camy the names of the authors and should be used and cired accordingly. The findings, interpretations, and conclusions are the authors oum and should not be atributed to the World Bank, its Executive Baard of Directors, or any of its member countries. 


\title{
Is Demand for Polluting Goods Manageable? An Econometric Study of Car Ownership and Use in Mexico
}

\author{
Gunnar S. Eskeland \\ Public Economics Division \\ Policy Research Department \\ World Bank \\ 1818 H Street, NW \\ Washington, DC 20433
}

and

Tarhan N. Feyzioglu

Department of Economics

Georgetown University

Washington, DC 20057

We would like to thank colleagues in Mexico, particularly Jorge D. Balmer at Instituto Nacional de Estadistica Geografia e Informatica, and colleagues at the World Bank for help with data and comments. We would also like to thank the participants of our seminar at the World Bank. 
Table of Contents

$\begin{array}{lc}\text { 1. Introduction } & \text { page } \\ \text { 2. Economic Model } & 1 \\ \text { 3. Dynamies: Short Run and Long Run Elasticities } & 12 \\ \text { 4. Data } & 14 \\ \text { 5. Econometric Issues } & 15 \\ \text { 6. Results } & 17 \\ \text { 7. Summary and Conclusions } & 24 \\ \text { References } & 27\end{array}$




\section{Introduction}

This econometric study is a part of a broader research effort on the economics of pollution control policies in developing countries. Our motivation for studying the determinants of demand for cars and gasoline is one of the many possible ones: we want to know the extent to which demand for polluting goods and services is sensitive to prices and income developments. The study and its results, however, should be of more general interest. It may be of interest from the point of view of an applied econometrician -- using some new techniques and data to examine an old problem with real-world data. constraints. It may also be of interest to those interested in demand for cars and gasoline, either because they may find good ideas on how to study the topic, or because they may find use for our actual results.

Our research project on the economics of pollution control policies in diveloping countries has emphasized two major lines of inquiry that has caused our interest in the demand for polluting goods and services. 1

One is that a potential, least cost program can deliver pollution reductions either by making each activity "cleaner" per unit of input or output (illustratively. we may call this cleaner cars and fuels, or technical controls), or by scaling down the level of polluting activities (we may call this fewer polluting trips). Such a least cost program could, theoretically at least, be induced by first best instruments such as tradeable emission permits or emission taxes, based on monitoring of individual emissions. If such programs had been in place, then one could estimate the emission reductions provided at different tax rates, at least in reduced form, and perhaps even recover the relative roles of cleaner trips and fewer trips. Given

1 Halvorsen and Ruby (1981), and Freeman (1982) present broader treatments of the costs and benefits of air pollution control. Harrison (1975) covers the same field, with an emphasis on vehicular emissions, and the distribution across households of costs and benefits. 
that such programs are not in place, however, one needs to go the indirect route of estimating the costs at which emission reductions can be provided through trip reductions and technical controls respectively. Such estimate can then be used to estimate both the control costs for potential least cost programs, and the excessive costs associated with programs that do not combine optimally the various ways by which emission reductions can be provided.

Another reason for inquiring about the demand for polluting goods and services such as cars and gasoline is our belief that costs of monitoring and enforcement of ten will make the use of first best instruments such as emission taxes difficult or impossible. When that is the case, the policy maker may need to evaluate the various ways by which emission reductions can be provided, in order to stimulate them separately ${ }^{2}$. For instance, for cars and trips, we may think of fees or sanctions associated with initial and periodic tests of emission factors as stimulating cars and fuels to be cleaner, while gasoline and road taxes, mass transport policies and parking fees are used to manage demand for polluting urban transport. 3

Perhaps for many reasons there is a rich body of econometric studies of demand on vehicles and fuels. General studies of demand for energy, and specific fuels among them, bloomed in the years following the first oil price shock in 1973, when

2 In Eskeland and Jimenez (1992), this point is elaborated in their distinction between direct instruments (based on monitoring of individual emissions) and indirect instruments (based on indicators of emissions, such as the characteristics of cars and other machinery as a proxies for "dirtiness", and fuel use or other measures as proxies for throughput).

3 The case for cleaner cars and fewer trips is examined in detail in Eskeland (1993), and Eskeland (1992). A program optimally combining instruments economizing on trips and making cars and fuels cleaner was found to cost 65 million dollars more per year, if the demand management instrument, a gasoline tax, was excluded, in favor of more aggressive technical controls. Since the 65 million dollar estimate was based in a more conservative price elasticity estimate than found in this study, we may now conclude that the costs of excluding demand management is higher.

Hau (1992 a and b), and Newbery et al. (1988) discuss charging road users, but to discourage road damage and congestion, rather than pollution. McConnell and Harrington (1992), Hahri (1993), Anderson (1990), Faiz et al. (1990) are examples of detailed studies of technical control options and costs. 
importing nations became concerned about their vulnerability to disruptions in imports andror price increases. The costs to an importing nation facing exogenous price shock will be higher the lower is the price elasticity of demand for the commodity in question. Among studies focusing on demand for energy, Fuss' 1975 study of energy use in Canadian manufacturing and Pindyck's book "The structure of world energy demand" probably are the most important: Fuss for demonstrating methodological breakthroughs concerning inter-fuel substitution, and Pindyck for a broad inquiry based on data from many countries, including developing countries.

Pindyck points out that there are reasons to believe that previous results based on the studies of developed countries should not be generalized to developing countries. It is conjectured that "as incomes rise, additional expenditures are not allocated proportionally to larger homes or to more heat or light in existing homes"; therefore, lower income countries should have higher income elasticities. In the same vain, at low income levels, most energy use is a necessity, whereas at high income levels, energy use "becomes more discretionary, allowing for greater substitution away from energy if prices rise"; therefore, lower income countries should have lower price elasticities.

Pindyck compares results he obtains from a developing country sub sample (Mexico and Brazil) with those from developed countries, and finds the results to be consistent with his expectations of lower price elasticities and higher income elasticities for gasoline: "The estimated price elasticity of demand is -.55 as compared to the estimate of about -1.3 obtained for the developed countries".."the income elasticity is 1.22 as compared to .8 for the developed countries". Comparing his results with those of many others, with lower elasticities, he concludes that (their) "use of data for a single country is more likely to elicit short- or intermediate-run elasticities" (page 233). 
Another, not entirely independent development of the 1970 s was regulatory changes to enhance environmental quality and fuel efficiency. With relevance for our topic, these developments gave emphasis to the distinction between fuel efficiency, measured for instance by liters consumed per kilometer and vehicle kilometers traveled by the average household. Manski (1983) proposed an elegant model of vehicle scrappage, and Bercovec (1985) estimated a model of vehicle demand by type including such a serappage model. Using this model, he could estimate the likely effect of vehicle regulations and the associated price increases for new vehicles, on the turnover and properties of the vehicle stock. Broader studies of the behavior of auto ownership and use, are found in, inter alia, Winston et al. (1987), Crandall et al. (1986), Ingram et al. (1975) and Grad et al. (1975). General equilibrium treatments of the effects of energy price increases and environmental regulations, with less emphasis on transportation and a particular fuel, are found in Jorgenson and Wilcoxen (1990), and in Hazilla and Kopp (1990).

There is also a literature of empirical studies based on discrete choice models ard micro-data, emphasizing the sensitivity of mode choice for individual trips to, inter-alia, pricing and travel times (see, for instance; Ben-Akiva and Lerman (1985)). Resuits from this literature are not generally comparable to those from aggregate data -- one of the most obvious reasons for this is that the modechoice models usually assume many variables as given in the outset (residential location, work-place location, car ownership). Due to these and other important differences between the two empirical bodies of literature, one should not be surprised that estimates of such parameters as the elasticity of car use to car operating costs will usually be much lower in these models than in aggregate models.

Two recent reviews that highlight findings in empirical models are Oum, Waters and Young (1990) and Krupnick (1992). Another recent study with both a review of 
results and empirical estimates is Sterner (1990). Sterner (1990) surveys close to a hundred different papers with 360 different estimated demand equations, and reestimates the models using a larger data base than those used in the studies he summarizes. He points to differences in results that may be seen as discouraging, but concludes that there is consistency in the results and that demand does "adapt to changes in both income and prices". For OECD countries, the sl.urt run elasticities from the dynamic models "appear to be around -0.2 to -0.3 and 0.35 to 0.55 for price and income respective!y". The long run elasticities were around -1.0 to -1.4 , and 0.6 to 1.6 for price and income respectively. For OECD countries, the results on price elasticities are consistent with those obtained by Pindyck, but the wide range for income elasticities cast a doubt on the claim that they should be systematically higher for developing countries.

Of special interest is, of course, Berndt and Botero (1985), who obtain elasticities for Mexico that are much closer to those reported for developed countries in Sterner. ${ }^{4}$ They present estimates from Mexico of a model of vehicle stock adjustments and gasoline demand, thus very similar to the objective of our study. They utilize a pooled cross-section time series data set and use the dynamic gasoline demand model discussed in Drollas (1984). For the short run, they find -0.23 for price elasticity and 0.31 for income elasticity. Long run price and income elasticities they find are -0.96 and 1.25 respectively.

There are several key issues that Berndt and Botero do not address. First, they use pooled cross-section time series data, aggregated to 14 regions; however, they do not consider possible differences between these regions, like geography and

4 The higher income elasticity for residential electricity demand in Mexico is explored by Berndt and Samaniego (1984). They point out that once the increase in demand for electricity do to increase in accessibility is taken into account, the remaining demand behaves similar to electricity demand in industrialized countries. Our study goes in the same direction for gasoline, distinguishing demand given the number of cars from the determinants of car ownership. 
infrastructure. Omission for possible differences between regions may lead to biased and inconsistent results. Second, they do not test whether the dynamics are adequately taken into account. In consequence, there could still be important dynamics left as residuals in their model. Third, they do not consider the effect of gasoline prices on new car sales. This results in the omission of the indirect effect of gasoline prices on gasoline consumption, thus ignores an empirical effect of interest in policy.

We address these and other issues that arise due to the nature of the data. We utilize a pooled cross-section time series data set with annual observations from the 31 states and the federal district in the Mexican Federation. We solve unobservability problem of the state specific effects by differencing the data. We explicitly take into account the possible dynamics in behaviors by incorporating it into the model, and by testing the residuals. We also deal with measurement error problems, specifically in state-wide GDP, by using instrumental variable estimation.

Section II introduces the economic model, and III presents dynamics and the relationship between short and long run elasticities. IV and V discuss data and econometric issues, respectively, and VI presents empirical findings. Summary and conclusions are found in a brief section VII. 


\section{Economic Model}

We start with the identity that the total gasoline consumption in Mexico is equal to the average consumption times the total number of vehicles, for each state and time period:

$$
G_{i t} \equiv C_{i t} s_{i t}
$$

where, $G_{i t}$ is the total gasoline consumption, $C_{i t}$ is the total consumption divided by the number of vehicles, and $S_{i t}$ is the stock of vehicles (number of cars), at time $t$, for state i.

There are two reasons for using this form. First, this decomposition lets us analyze the role of the car stock and the average utilization rate separately. We have in mind a model in which there is a fixed cost of having a car available, associated with sar prices, and a variable utilization cost, associated with gasoline prices. In such a model, gasoline consumption as well as car ownership will depend on car prices, gasoline prices and income. 5

Second, this form lets us calculate the price and income elasticities easily. Elementary calculations show that the gasoline price elasticity of consumption is the sum of price elasticities for per car consumption and total number of cars:

$$
\eta_{t}=\eta_{c}+\eta_{5}
$$

where, $\eta_{t}$ is the gasoline price elasticity of total consumption, $\eta_{c}$ is the gasoline price elasticity of gas consumption per car, and $\eta_{s}$ is the gasoline price elasticity of car stock.

Next, we turn to modeling each component of this identity. First, we model gasoline consumption per vehicle, for a given number of vehicles. We assume a representative consumer with a utility function separable in services rendered by a

5 Throughout, we shall work with three market goods and their prices; gasoline, cars and other goods and services. We normalize each price by the price of other goods and services, thus reducing the analysis to two prices only. 
car and other goods and services. We assume the services from the car are proportional to gasoline usage. In addition to prices and income, there may be differences between states, like geographies and infrastructure that affect gasoline consumption. These additional effects are not observable to us, but we can summarize them in a state specific variable, $\alpha_{i}$, that is constant through out years, but varies across states. We also incorporate habit persistence by considering the lagged values of the dependent variable, and write the consumption function in the following form:

$$
c_{i t}=f\left(\bar{C}_{i t-1}, G A S P R_{t}, Y_{i t} ; \alpha_{i}, \theta\right)
$$

where, GASPR ${ }_{t}$ is the gasoline price, $Y_{i t}$ is income, $\bar{C}_{i t-1}$ is the vector of past consumption rates, $\alpha_{i}$ is a scalar that allows for the state specific characteristics, $\theta$ is the vector of parameters dictated by the functional form, and $f(\cdot)$ is. the function implied by the first order conditions. 6

Second, we model the car stock. We assume that there is an optimal car stock level for each state. Consumers in each state would calculate how much car services they want, given the prices and their incomes. As relevant prices for this choice, they consider car prices and gasoline prices. The reason why we include gasoline

6 Note that we assume that car prices do not effect izasoline consumption per car. To examine this assumption in detail, assume that consumption fier car is average fuelefficiency of the car stock times the average miles driven:

$$
C=e^{*} t(I, C A R P R, G A S P R)
$$

where, $e$ is the overall stock fuel-efficiency rate and $t$ is miles driven. Then we can decompose the change in utilization rate into two, one due to change in efficiency, the other, due to change in number of trips made:

$$
\text { aC/OCARPR }=(\text { Je/OCARPR }) * t+(\partial t / \partial C A R P R) * e
$$

Change in average fuel-efficiency due to an increase in car prices should be zero or negative since less old cars will be scrapped and fewer new purchased. A nice piece of evidence to this effect is found in Kahn (1986). On the other hand, car prices will reduce or have no effect on number of cars in the stock, and this in turn will, if anything, increase the trips taken by each car. Our assumption that gasoline consumption per car is independent of car prices thus amounts to assuming the sum of these two effects equal zero. 
prices is that we believe consumers do take into account the marginal cost of running a car in their purchasing decisions. They may calculate the total discounted cost of gasoline consumption into the car price. This implies that as gasoline prices increase, we should expect a decrease in the car stock. However, if new cars are more fuel efficient, then new car sales might increase as gasoline prices increase. Considering both arguments, we do not know a priori which direction the gas prices may affect car stock.

We can summarize these in the following optimal stock level equation:?

$$
s_{i t}^{*}=s\left(\text { CARPR }_{t}, \text { GASPR }_{t}, Y_{i t}, \alpha_{i} ; \xi\right)
$$

where $S_{t}$ is the optimal car stock level, $Y_{i t}$ is the income level, CARPR is a price index for new cars, $\alpha_{i}$ is a scalar for each state, representing state specific characteristics, $\xi$ is a vector of unknown parameters.

If there are adjustment costs in the car stock, the car stock may deviate from the optimal stock. To allow for this possibility, we decompose the current actual car stock into the depreciated car stock that remained from the previous year and the new car purchases:

$$
S_{i t}=(1-\delta) S_{i t-1}+I_{i t}
$$

where, $S_{t}$ is the stock of cars, $I_{t}$ is the new car purchases, and $\delta$ is the depreciation factor.

For depreciation, we shall consider two alternatives. The first one is the constant depreciation rate that does not change across the states or through out the years. While this is a commonly used assumption, we believe it should be tested. It can be argued that the higher the new car prices, the higher the value of the used

7 The optimal stock decision depends on the expected value of the service flow, and the costs of hoiding the car for one period (where a "period" should be long enough that the transaction costs are not overwhelming). The relationship between holding costs and car prices may not be one to one, so our estimate of $\operatorname{as}_{t} / \partial \mathrm{CARPR}_{t}$ is a reduced form estimate. 
cars would be, and the less the number of cars that would qualify to be scrapped. An elegant model is given by Manski (1980), and applied successfully to the US market by Berkovec (1985). In addition, as gas prices go up, if older cars have lower fuel efficiency, scrappage should increase. Similar reasoning goes for an income increase: the higher incomes are, the less they would be willing to use and repair old cars. We may test a model allowing the depreciation rate to depend on these factors:

$$
\delta_{i t}=d\left(C^{\prime} A R P R_{t}, G A S P R_{t}, Y_{i t}\right]^{\prime}
$$

where $\mathrm{d}(-)$ stands for the functional form for the depreciation rate.

The second component in equation (5), new car purchases, should be a function of the optimal car stock. Higher incomes, or lower car prices would increase the optimal car stock which in turr would increase new car sales.

But there is also a mechanism through which new car purchases depend on the car stock from the previous year. If a partial adjustment model is assumed, this dependence would be reflected in the adjustment factor, which describes the extent to which a difference between the optimal stock and the previous year stock is closed within a year. 8 A linear partial adjustment model implies a negative, close to unity relationship between the new car purchases and the previous year stock, simply because the new car purchases are equal to a given fraction the optimal stock, less whatever remains from the previous year. However, Pindyck (1979) and Berndt and Botero (1985) have found evidence against these models; therefore we are not going to

8 The simple stock adjustment model assumes that, each period, consumers buy new vehicles to close some fraction of the gap between the optimal stock and the depreciated stock from previous year:

$$
\begin{gathered}
S_{t}-(1-\delta) S_{t-1}=\gamma\left(S_{t}-(1-\delta) S_{t-1}\right) \quad 0 \leq \gamma \leq 1 \\
I_{t}=\gamma\left(S_{t}-(1-\delta) S_{t-1}\right)
\end{gathered}
$$

where $I_{t}$ is the new car purchases, $S_{t}^{*}$ is the optimal stock, $\delta$ is the depreciation factor, and $\gamma$ is the adjustment factor. 
restrict the functional form to strict linear partial adjustment model.

A less restrictive stock adjustment model is allowed by the following formulation:

$$
I_{i t}=i\left(S_{i t}, S_{i t-1}, \alpha_{i} ; \gamma\right)
$$

where $\gamma$ is the parameter vector, and $\mathrm{i}(\cdot)$ indicates the functional form.

Several caveats are in order. First, we should emphasize that we assume that gasoline prices and car prices are exogenously determined. Apart from believing these assumptions are plausible, testing them would require more supply side information, and is outside the scope of this study.

Second, we assume that gas consumption per car is independent of the number of cars. It can be argued that in metropolitan areas, if road space does not increase commensurately with the number of cars, traffic congestion may increase. This in turn would iscrease gasoline consumption per mile, and perhaps also reduce miles traveled. At a different vein, it can also be argued that number of cars may be increasing because households buy their second, or third car. This will on average reduce the gasoline consumption per car if the total usage is less than proportional to the number of cars. We believe that the net effect of these on the questions we are looking at are negligible, especially given that we look at the whole nation, not only the metropolitan areas, and that only few families have more than one car in Mexico: Never-the-less, it is an interesting question that needs further analysis with housetsold level data.

Third, since we are using aggregate data at the state level in this study, we are not decomposing the source of heterogeneity in the consumption and investment behavior into individual level. We characterize each state by a state specific unobserved variable that does not change through time, and its income. But we are 
unable to analyze phenomena such as the importance of variation of within state income distribution, household size, age distribution, etc.

Fourth, when assuming separability between car services and other consumption, we do not consider particular changes in prices among other goods and services, such as changes in the availability or price of alternative transportation modes. A substantial change in public transportation capacity and price would likely change the pattern of new car purchases and average gasoline consumption in a particular way, but is only captured through its effect on the overall price of other goods and services in our model. Consicier, for example, a decrease in the price of public transportation coupled with a capaciry increase. Consumers who marginally decide to own and use a car would prefer to use public transportation, and the demand curve for car services would shift inwards. In consequence, the average income of the people who have cars would go up. If such an incidence occurred, our analysis would only capture the fact that the incomes at which cars are bought was shifted upward, and the cross price effect to these goods and services was substantial. In consequence, our estimates would be too low for income elasticity and too high for price elasticity, compared to a model identifying the prices and quantities of alternative modes. 9

\section{Dynamics: Short Run and Long Run Elasticities}

We assume constant income and price elasticities of gasoline consumption and investment in cars by estimating functions linear in logarithms. Also, we differentiate between the short run and the long run elasticities by formulating the equations in a dynamic form. This is done by ircluding lagged dependent variables as

9 The opposite would be true, of course, if price changes of other goods and services occurred predominantly among goods and services of little relevance to car and gasoline demand. 
explanatory variables.

From the consumption behavior defined in equation (3) we obtain the following utilization equation (or gasoline consumption per car):

$$
\ln C_{i t}=\beta_{0}+\alpha_{i}+\sum_{i=1}^{\ell} \beta_{i} \ln C_{i t-i}+\theta_{1} \ln G A S P R_{t}+\theta_{2} \ln Y_{i t}+\varepsilon_{i t}
$$

where $C_{i t}$ is gasoline consumption, GASPR $t$ is the gasoline price, $Y_{i t}$ is income, $l$ is the appropriate lag length, $\alpha_{i}$ are the individual state effects, and $\varepsilon_{i t}$ is the idiosyncratic error term that is assumed to be uncorrelated through time and across states. The parameters $\theta_{1}$ and $\theta_{2}$ can be interpreted as short run price and income elasticities respectively.

Similarly, we assume that the investment equation and the optimal stock equation are linear in the logarithm of their arguments. After substituting equation (4) into (7), we obtain the investment equation for new car purchases:

$$
\begin{aligned}
\operatorname{lnI}_{\mathrm{it}}=\gamma_{0} & +\phi_{\mathrm{i}}+\sum_{\mathrm{i}=1}^{k} \gamma_{\mathrm{i}} \ln \mathrm{I}_{\mathrm{it}-\mathrm{i}}+\varphi_{1} \ln C A R P R_{t} \\
& +\varphi_{2} \operatorname{lnGASPR_{t}}+\varphi_{3} \ln Y_{i t}+\varphi_{4} \ln S_{i t-1}+v_{i t}
\end{aligned}
$$

where $I_{i t}$ is the investment variable, CARPR $t_{t}$ is the car price index, $k$ is the appropriate lag length, $\phi_{i}$ are the individual state effects, and $\nu_{i t}$ is the idiosyncratic error term that is uncorrelated through time and across states. Arguments similar to those for the utilization equation (8) follow here too. The parameters $\varphi_{1}, \varphi_{2}$ and $\varphi_{3}$ are interpreted as short run price and income elasticities for new car sales.

While short run elasticities for gasoline consumption per car are readily seen as the coefficients of the price and income variables, the long run elasticities have to be calculated from the dynamics of the utilization equation. We calculate the 
implied long run elasticities for gasoline consumption per car by solving the difference equations defined by setting the errors to zero.

It is trickier to calculate the elasticities for the car stock. For the short run, tile elasticities are the price and income elasticities of investment times the ratio of investment to car stock 10 In the long run, stocks should be equal to the desired stock level $S^{*}$ and to stable incomes, investment should be equal to depreciation. Therefore, the long run elasticities for the car stock are equal to the investment elasticities times the depreciation factor. Long run investment elasticities, of course, like gasoline consumption per car, have to be calculated by solving the difference equation defined by the investment equation.

Frorn these elasticities, we can calculate the elasticities for total gasoline consumption. Due to the identity in equation ( $\mathrm{I}$ ), the natural logarithm of total gas consumption is equal to the sum of natural logarithms of per car consumption and car stock. Therefore, the elasticities for total gas consumption is the addition of elasticities for consumption and the car stock.

IV. Data

The data is collected across 31 states and the federal district in Mexico from 1982 through 1988.

The disaggregated data on income is obtained from Escudero and Rivas (1989). National income data is available annually; however disaggregated income for each state is published only eyery fifth year. Escudero and Rivas (1989) use the Chow and Lin (1971) method to model income levels by state for the years not published.

To The reason for this is the lack of a direct stock equation that depends on prices and income. However, we can derive the required elasticities by manipulating the investment equation. Today's stock is equivalent to today's investment plus last year's depreciated stock. Therefore, one percentage increase in investment implies an increase in stock that is equal to one percentage times the ratio of investment to stock. 
Gasoline consumption $c_{i t}$ are calculated by dividing the total gasoline consumption for each state by the corresponding number of vehicles in stock from vehicle registration data, Bureau of Statistics. Throughout this study, only cars are considered. The gasoline price GASPR $t$ is the price of "nova", and does not include "extra" or diesel.11 All quantity variables are divided by the corresponding population numbers.

New car sales is from the association of automobile manufacturers, which publishes sales by state. Imports are negligible.

Whenever an "ln" precedes a variable name, it means that that variable is used in logarithmic form.

\section{Econometric Issues}

Simple application of Ordinary Least Squares (OLS) method would result in parameters that are biased and inconsistent. This is due to the combination of three econometric issues: i) the unobservability of the state specific individual effects, ii) the dynamic specification that allows for habit persistence, and iii) measurement errors in the data set. A method that is capable of remedying these three problems is the instrumental variable (IV) estimation method. In the rest of this section, we discuss these issues and remedies in detail.

The first issue is the possibility of individual, unobservable characteristics that influence a state's demand for given prices and income. Ideally, variables representing these characteristics should be included, to avoid the omitted variable problem. A state specific constant is introduced to summarize the effect of such differences between states, to the extent that the characteristics do not change over time. To the extent state characteristics change over time (in a way that is not

II As of 1988, nova amounted to 99.57 of the gasoline consumption for cars. 
fully reflected in changes in income, for example) our model is unable to capture this.

The second econometric problem is due to the dynamic nature of the model ${ }^{12}$. If there is a lagged endogenous variable as an explanatory variable, then the variance components estimator under the random effects model and the least squares dummy variable estimator under the fixed effects model are biased and for fixed time series also inconsistent.

The third issue is the errors we have in the income variable. Even if we assume that the disaggregate income figures are correct for the years that are published, intermediate years are only estimates of the actual figures and therefore have ersors in them. Due to the interpolation methodology, the errors are uncorrelated across time and across individuals, but never-the-less, any error is sufficient to cause the OLS estimators to be inconsistent.

We can solve the first problem by using the differenced data, i.e., by redefining the variables to be changes across years, or by using the Least Squares Dummy Variable Estimation (LSDV) or Covariance Estimation (CV) methods ${ }^{13}$. If we difference the data, the individual effects, whether they are fixed or random, would cancel out because these effects do not change over time. If this were the only problem, after differencing, OLS estimation method would have given unbiased and consistent estimates. However, having a lagged dependent variable as an explanatory variable or having measurement errors, render OLS, LSDV and CV estimation methods invalid 14.

The second and the third problems can be solved through the method of

I2 For a good exposition, see Hsiao (1986).

13 For further details, see Hsiao (1985).

14 See Hsiao (1985). 
instrumental variable (IV) estimators. If we find instruments that are highly correlated with the explanatory variables, but not correlated with the errors, we can obtain consistent estimates of the coefficients, even for panel data with short time series.

The instruments we have chosen are lagged values of the gasoline consumption and lagged values of income. Since the data is differenced for estimation, the second lag of gas consumption will be correlated with the lagged differenced gas consumption that shows up as an explanatory variable, but it will not be correlated with the error term. Similarly, the second lag of income will be correlated with the differenced income variable, but because the measurement errors are uncorrelated, this instrument will also be uncorrelated with the error term. For estimation, we used the optimal instruments in the sense that for time $t$, we included all the second lags of the instruments up to $t-2$.

\section{Results}

As mentioned, the utilization equation is estimated by differencing the data to wipe out the individual effects. The lag length is chosen by the first lag that does not have leave second order serial correlation in the residuals. The results for the utilization equation are: 15

\footnotetext{
15 All the numbers in parenthesis are the standard errors of the coefficient estimates.

Wald test tests for the significance of the overall regression.

Sargan test has the null hypothesis that there is no specification error, including the choice of the instruments. The test statistic is distributed $\chi 2$ under the null hypothesis. A Sargan Test Statistic that is too high with respect to the degrees of freedom indicates misspecification.

Robust test for serial correlation tests for serial correlation in the error terms. In differenced data, we expect first order serial correlation, but not second order serial correlation. This test statistics is distributed standard normal under the null hypothesis of no serial correlation. A statistic that is greater than 2 in absolute value indicates serial correlation.
} 


$$
\begin{aligned}
\operatorname{lnC}_{i t}=0.154 \ln C_{i t-1} & -0.137 \ln C_{i t-2} \\
(0.025) & (0.014) \\
& -0.785 \operatorname{lnGASPR}{ }_{t}+0.822 \operatorname{lnGDP} P_{i t}+e_{i t} \\
& (0.100)
\end{aligned}
$$

Wald test of joint significance: $284.82 \mathrm{df}=4$

Sargan Test: 20.61 df $=21$

Robust test for first order serial correlation: -0.969

Robust test for second order serial correlation: -0.003

The t-statistics obtained by dividing the coefficients by the standard errors indicate that all the coefficients are significantly different from zero at $95 \%$ confidence level. The significance of the overall regression is also confirmed by the Wald test statistic. Sargan test accepts the set of instruments used in the estimation, and the robrist test for second order serial correlation indicates that there is no detectable correlation in the error term.

The short run and the implied long run elasticities are as follows: 16

Table 1: Elasticities for Gasoline Consumption per Car

\begin{tabular}{|l|c|c|}
\hline & Short Run & Implied Long Run \\
\hline Gasoline Price Elasticity & -0.785 & -0.799 \\
\hline income Elasticity & 0.822 & 0.836 \\
\hline
\end{tabular}

The closeness of the short run and the long run elasticities imply that the economic agents tend to adjust almost fully within a year to changes in price or in income. This may seem counter intuitive, given that lagged dependent values are statistically significant. However, even though past values affect current values, these effects cancel each other out in the long run, since in the long run, there is no past effects.

16 The steady-state implied by the model is $\ln C=0.154 \ln C-0.137 \ln C-0.785 \ln G A S P R+0.822 \ln G D P$. When solved for $\ln C$, we obtain the long run elasticities in table 1. 
The long run elasticity estimates are close to what Berndt and Botero (1985) find (-0.96 and 0.94 respectively). However, their estimate of the short run elasticities fall far short of our estimates. In their study, they use only one lag of the dependent variable which has a high coefficient. In our study. we showed that there is still considerable serial correlation in the residuals that warrant for a second lagged dependent variable. Tiis second lag brought down the difference between the long run and the short run effect.

The investment equation is also estimated in differences. The results for the investment equation are:

$$
\begin{aligned}
& \operatorname{InI}_{\text {it }}=-0.684 \operatorname{InCARPR}_{\tau}+0.281 \operatorname{lnGASPR} \mathrm{R}_{\tau} \\
& (0.029) \quad(0.113) \\
& +3.893 \operatorname{lnGDP}_{i t}+0.075 \ln \mathrm{S}_{i t-1}+\mathrm{e}_{\mathrm{it}}
\end{aligned}
$$

Wald test of joint significance: $2881.59 \mathrm{df}=4$

Sargan Test: $24.48 \mathrm{df}=20$

Robust test for first order serial correlation: -1.972

Robust test for second order serial correlation: 0.013

The t-statistics indicate that all the coefficients except the coefficient of the lagged stock variable are significantly different from zero at 957. confidence level. The coefficient of the lagged stock variable is significant at $90 \%$ confidence level. Similar to the utilization equation, Sargan test accepts the set of instruments used in the estimation, and the robust test for second order serial correlation indicate that there is no detectable correlation in the error term.

For this model, even though dynamics were allowed in this regression, there are no lagged dependent variables because the robust statistics indicated that there were no dynamics detectable in the error terms. 
The elasticities are as follows:

Table 2: Elasticities for New Car Sales

\begin{tabular}{|l|c|}
\hline Car Price Elasticity & -0.684 \\
\hline Gas Price Elasticity & 0.281 \\
\hline Income Elasticity & 3.893 \\
\hline
\end{tabular}

These results contrast those of Berndt and Botero (1985)'s finding that gasoline prices do not effect new car sales, income elasticity is unity, and car price elasticity is -1.34. We believe the difference is primarily due to the fact that we kept the gasoline prices in the regression and we took into account possible differences between states which they omitted. Thus difference in car purchases between states, that they had to relate to income differences between states, are, in our model, to a greater extent explained by the state specific constants.

The coefficient of the gasoline prices is positive. This result cannot be ruled out a priori on theoretical grounds, if we allow for the fact that new cars may be more fuel-efficient. The efficiency interpretation dictates that, as gas prices go up. the gasoline savings offered by newer cars make them more attractive, so the gas price elasticities of new cars could be positive. However, we should expect that older cars are either scrapped or transferred to lower utilization rates.

The coefficient of the lagged car stock is positive, and significant. It is also in line with other studies that use a variation of partial adjustment model ${ }^{17}$.

The stock equation is estimated by imposing a unit coefficient on the investment variable and assuming that depreciation factor is the same across the states and 17 Berndt and Botero (1985), Pindyck (1979). 
through out the years. The results for the stock equation are: 18

$$
S_{i t}=4926+0.970 S_{i t-1}+I_{i t}+e_{i t}
$$

Wald test of joint significance: $13598.8 \mathrm{df}=1$

Robust test for first order serial correlation: -0.176

Robust test for second order serial correlation: -0.969

The results imply that the depreciation rate, (or scrappage actually) is quite low at approximately $3 \% .19$. This is the net depreciation rate and therefore is the depreciation that remains after repairs are done to the cars.

An alternative stock equation is estimated, allowing depreciation be a function of gasoline prices, car prices and incorne. We performed a sensitivity analysis and chose a quadratic approximation to this unknown function:

$$
\begin{aligned}
& \delta_{i t}= \delta_{0}+\delta_{1} \operatorname{lnGASPR}_{t}+\delta_{2} \ln ^{2} \text { GASPR }_{t} \\
&+\delta_{3} \operatorname{lnCARPR}_{t}+\delta_{4} \ln ^{2} \text { CARPR }_{t}+\delta_{5} \operatorname{lnGDP}_{i t}+\delta_{6} \ln ^{2} \mathrm{GDP} \\
& \mathrm{it}
\end{aligned}
$$

We assume that this relationship is exact and substitute into equation (4). The results are

$$
S_{i t .}=\underset{(2138)}{3763+\left(1-\delta_{i t}\right) S_{i t-1}}+I_{i t}+e_{i t}
$$

where,

$$
\begin{aligned}
& \delta_{\text {it. }}=-20.34+16.46 \operatorname{lnGASPR} t+16.391 n^{2} \text { GASPR }_{t} \\
& \text { (7.030) (2.938) (2.756) } \\
& +18.181 n \text { CARPR }_{t}-2.945 \ln ^{2} \text { CARPR }_{t}-0.550 \operatorname{lnGDP}_{i t}+0.021 \mathrm{ln}^{2} \mathrm{GDP}_{i t} \\
& \text { (4.356) }
\end{aligned}
$$

Wald test of joint significance: $6592.42 \mathrm{df}=7$

Robust test for first order serial correlation: -0.026

Robust test for second order serial correlation: -1.844

18 The unit coefficient is imposed by using $S_{i t}-I_{i t}$ as the endogenous variable. : 19 Similar to Berndt and Botero (1985). 
The estimation results show that depreciation rate is affected significantly by prices and income. Strong price effects on scrappage were also found in Berkovec (1985). Both gasoline prices and car prices have the expected effects: as gasoline prices go up, on average, people would want to use more efficient cars, and scrap the old and inefficient cars. Similarly, as car prices go up, on average, people would buy less new cars, the prices and the value of second hand cars would go up, and this would lead to a decrease in the scrappage rate (as in the theoretical model of Manski(1983)). Income also has the expected effect on the depreciation rate. The incomes go up, scrappage increases. An interesting observation which may reflect on phenomena related to income distribution is that the distribution of the increase in income was such that not only did it lead to more new car sales, but also to greater scrappage of older cars.

The implied depreciation rate is on average 4.7\%. The rates are not restricted to be between zero and one, but except the rates for 1988, almost all of them are positive and close to the average. In 1988, there is a dramatic decrease in the car. price index, an this pushes the depreciation rate to a region on the quadratic form such that the car prices and depreciation are positively correlated, and the resulting rates are negative. In general, however, the results are significant, and as expected a priori.

We can use the results presented above to calculate the elasticity of total gasoline consumption. So far, the gasoline consumption elasticities are calculated, keeping the car stock coristant. However, total gasoline consumption varies not only due to changes in consumption per car, but also due to changes in the car stock. Equation (1) dictates that the total elasticities can be obtained by simple addition 
of consumption elasticities and the stock elasticities.

We calculate the short run stock elasticities by multiplying the investment elasticities by the average investment to stock ratio. The short run income elasticity of car stock is calculated to be 0.156 , which is the average investment to stock ratio 0.04 times the income elasticity of investment, 3.893. The short run car price elasticity of the car stock is -0.025 , which is the car price elasticity of investment times 0.04 .

The long run elasticities of the car stocik are equal to the depreciation rate times the investment elasticities. If we use the average depreciation rate that we obtained from the variable depreciation rate model, then the income elasticity turns out to be 0.183 . Similarly, the long run car price elasticity of car stock is -0.029 .

Table 3: Elasticities for the Car Stock

\begin{tabular}{|l|c|c|}
\hline & Short Run & Long Run \\
\hline Car Price Elasticity & -0.025 & -0.029 \\
\hline Income Elasticity & 0.156 & 0.183 \\
\hline
\end{tabular}

The elasticities for the car stock calculated above exclude the possible changes in the number of cars that would be scrapped due to price or income changes. If we use the variable depreciation defined by equation (10), and use the averages of prices and income, the gasoline price elasticity of car stock becomes 1.127, the car price elasticity of car stock changes by -0.675 , and income elasticity of car stock increases by 0.056 . However, especially for price elasticities, the variances are very large and confidence intervals include zero values. Therefore, we have excluded the effects of scrappage change due to a price or income change. The net effects could be negligible, but if anything, should be in the direction implied by the depreciation estimation results. 
The total elasticities for gasoline consumption can be obtained by adding up elasticities for gasoline consumpion per car and elasticities for car stock:

Table 4: Elasticities for the Total Gasoline Consumption

\begin{tabular}{|l|c|c|}
\hline & Short Run & Long Run \\
\hline Gasoline Price Elasticity & -0.785 & -0.799 \\
\hline Car Price Elasticity & -0.025 & -0.029 \\
\hline Income Elasticity & 0.978 & 1.019 \\
\hline
\end{tabular}

We have also identified three states that had incomes substantially higher then the rest. We used dumny variables to differentiate these states and we also let the dummy variables interact with the income and price variables. The results were that non of the coefficients of the dummy variables were significantly different from zero. This implies that there is no significant difference in elasticities between the rich states and the rest. We present these results without regression outputs not to crowd the exposition with irrelevant material. 20

\section{Summary and Conclusions}

Assuming that demand for cars and their use is determined, predominantly, by income, prices of vehicles, fuels and other goods and services, we have used a data set with aggregate data from 31 states and the federal district over 7 years in Mexico to estimate a demand model. The model, with optimal stock adjustments, displays almost full adjustment within a year, and the price elasticity of total gasoline consumption is -.79 in the short run and -.8 in the long run.

A long run income elasticity of one in Mexico is in the same range as those

20 Details can be obtained from the authors. 
found for developed countries in most studies summarized in Sterner. The elasticities deviate somewhat from those of Pindyck, and Berndt and Botero who find higher long run income elasticities.

The long run price elasticity turns out to be higher than those found by Pindyck, and close to the lower end of those estimated for developed countries in Sterner. Even though this estimate is lower that the ones found in Berndt and Botero, the difference is not significant.

The most important difference in terms of estimated parameters may be that our model displays a more rapid adjustment, so that our short term elasticities are higher. We believe we have found better ways of dealing with the dynamics in this market, and thus that our results may be worth some attention.

From a policy perspective, on the other hand, one should be mostly concerned with the long term elasticities. When these are large, as in our case, it is clear that pricing matters a great deai for demand. In the case of polluting goods and services, it shows that demand management will be important in delivering emission reductions in a low cost control program. Another way of stating this fact is that the social costs of adopting pricing policies which do not reflect social costs (costs of production and pollution, for instance), will be high, because the consequent behavioral adjustments will be large.

The fact that demand is responsive may also be used as inputs in discussion of other demand management instruments, such as parking fees, subway fares, tolls, cordon pricing, etc. As pointed out elsewhere, the slope of the demand curve can be viewed as an expression of the costs to consumers of sacrificing a marginally attractive trip. In that context, one need be careful with certain aggregation issues. The most important one is, perhaps, the fact that the slope of the demand curve that we have estimated here is an aggregate demand curve, and thus that there 
are income distribution effects associated with demand management instruments. Thus, the curve reflects how trips would be sacrificed according to willingness to pay at different price levels, with a self selection of trips between households as well as for each household. The incidence among households requires analysis of data at the household level. Also, if revenue generating instruments such as gasoline taxes are used, assumptions need be made about how the revenues are used or redistributed.

Our motivation was to find out whether demand for these goods and services is at all responsive to demand, and the results yield little support for "elasticity pessimism". 


\section{References}

Anderson, Robert. (1990). "Reducing Emissions from Older Vehicles." American Petroleum Institute, Washington, D.C.

Arellano, M. and S. R. Bond. (1991). "Some Tests of Specification for Panel Data: Monte Carlo Evidence and an Application to Employment Equations." Review of Economic Studies, 58 pp 277-297.

Ben-Akiva, Moshe, and Steven R. Lerman. (1985). Discrete Choice Analivsis: Theory and Application to Travel Demand. MIT Press: Cambridge, Massachusetts.

Berkovec, James. (1985). "New Car Sales and Used Car Stocks: A Model of the Automobile Market." The Rand Journal of Economics, vol. 16 no. 2, pp. 195 - 214.

Berndt, E. R. and G. Botero. (1985). "Energy Demand In the Transportation Sector of Mexico." Journal of Development Economics, 17 pp. 219-238.

Berndt, E. R. and R. Samaniego. (1984). "Residential Electricity Demand in Mexico: A Model Distinguishing Access from Consumption." Land Economics pp. $268-277$.

Chow, G. C. and A. Lin. (1971). "Best Linear Unbiased Interpolation, Distribution and Extrapolation of Time Series by Related Series." Review of Economics and Statistics, vol 53, pp. 372-375.

Crandall, Robert W., Howard K. Gruenspecht, Theodore E. Keeler and Lester B. Lave. (1986). Regulating the Automobile. The Brookings Institution.

Drollas, L. P.. (1984). "The Demand for Gasoline: Further Evidence." Enersy Economics, 6, pp. $71-82$.

Escudero, A. P. and J. A. H. Rivas. (1989). "Un Modelo de Desagregacion Geografica: Estimation del Pib por Entidad Federativa, 1970-1988." Serie de Documentos de Investigacion, Numero 1, Instituto Nacional de Estadistica Geoggrafia e Informatica.

Eskeland, Gunnar S. (1992). "Attacking Air Pollution in Mexico City." Finance $\underline{\&}$ Development pp. $28-30$.

Pollution Control Program for Mexico City." Policy Research Working Paper 1076, World Bank, Washingtor, D.C.

and Emmanuel Jimenez. (1992). "Policy Instruments for Pollution Control in Developing Countries." The World Bank Research Observer pp. 145 - 169.

Faiz, Asif, Kumares Sinha, Michael Walsh and Amiy Varma. (1990). "Automotive Air Pollution: Issues and Options for Developing Countries." World Bank Working Paper Series 492, August.

Freeman, A Myrick, III. (1982). Air and Water Pollution Control: A Benefit-Cost Assessment. John Wiley \& Sons: New York. 
Grad, Frank P. Albert J. Rosenthal, Laurie R. Rockett, James A. Fay, John Heywood, John F. Kam, Gregory. K. Ingram, David Harrison, Jr.,. Thomas Tietenberg. (1975). The Automobile and the Regulation of Its Impact on the Environment. University of Oklahoma Press: Norman, Oklahoma.

Hahn, Robert W. (1993). "Choosing Among Fuels and Technologies for Cleaning UP the Air." American Enterprise Discussion Paper, American Enterprise Institute, Washington, D.C.

Halvorsen, Robert, and Michael G. Ruoy. (1981). Benefit-Cost Analysis of AirPollution Control. D.C. Heath and Company: Lexington, Massachusetts.

Hansen, L. P. (1982). "Large Sample Results for Generalized Method of Moments Estimators." Econometrica. 50, pp. 1029 - 1054.

Harrison, David, Jr. (1975). Who Pavs for Clean Air. Ballinger Publishing Company: Cambridge, Massachusetts.

Hau, Timothy D. (1992a). "Economic Fundamentals of Road Pricing: A Diagrammatic Analysis." Policy Research Working Paper 1070, World Bank, Washington, D.C.

_ (1992b). "Congestion Charging Machanisms for Roads: An Evaluation of Current Practice." Policy Research Working Paper 1071, World Bank, Washington, D.C.

Hazilla, Michael and Raymond J. Kopp. (1990). "Social costs of environmental quality regulation: a general equilibrium analysis." Journal of Political Economy, August, 98 (4), pp. 853-73.

Jorgenson, Dale W. and Peter J. Wilcoxen (1990). "Environmental Regulation and U.S. Economic Growth." Rand Journal of Economics, Vol. 21, No. 2 pp. $314-340$.

Kahn, James A.. (1986). "Gasoline Prices and the Used Automobile Market: A Rational Expectations Asset Price Approach" The Quarterly Journal of Economics, pp. 323 339.

Krupnick, Alan J.. (1992). Measuring the Effects of Urban Transportation Policies on the Environment: A Survey of Models." Policy Research Working Paper 1030, World Bank, Washington, D.C.

Manski, C.. (1983). "Analysis of Equilibrium Automobile Holdings in Israel with Aggregate Discrete Choice Models." Transportation Research B, vol17B, no 5, pp. 73 389.

McConnell, Virginia and Winston Harrington. (1992). "Cost-effectiveness of Enhanced Motor Vehicles Inspection and Maintenance Programs." Discussion Paper QE92-18, Resources for the Future, Washington, D.C.

Mackinnon, James G. and Russell Davidson. (1993). Estimation and Inference in Econometrics. Oxford University Press: New York.

Newbery, David M., Gordon A. Hughes, William D.O. Paterson, and Esra Bennathan. (1988). "Road Transport Taxation in Developing Countries: The Design of User Charges and Taxes for Tunisia." World Bank Discussion Paper 26, Washington, D.C. 
Oum, Tae H., W.G. Waters, II, and Jong Say Yong. (1990). "A Survey of Recent Estimates of Price Elasticities of Demand for Transport." Policy, Planning, and Research Working Paper 359, World Bank. Washington, D.C.

Pindyck, R.. (1979). The Structure of World Energy Demand. The MIT Press, Cambridge.

Sterner. Thomas. (1990). The Pricing of and Demand for Gasoline. Swedish Transport Research Board, Stockholm, Sweden.

Winston, Clifford and Associates. (1987). Blind Intersection? Policy and the Automobile Industry: The Brookings Institution: Washington, D.C. 


\section{Appendix I}

Equation ( 8 is estimated in the following form:

$$
\Delta \ln C_{i t}=\sum_{i=1}^{\ell} \beta_{i} \Delta \ln C_{i t-i}+\theta_{1} \Delta \operatorname{lnGASPR} R_{t}+\theta_{2} \Delta \ln Y_{i t}+\varepsilon_{i t}
$$

where, $\Delta$ is the difference operator, e.g. $\Delta C_{i t}=C_{i t}-C_{i t-1}$ The individual effects, $\alpha_{i}$, disappear because of differencing. Residual Tests indicated the necessity of setting $\Psi=2$; therefore, estimation was done by taking the first three years as initial values. The optimal instrument matrix is

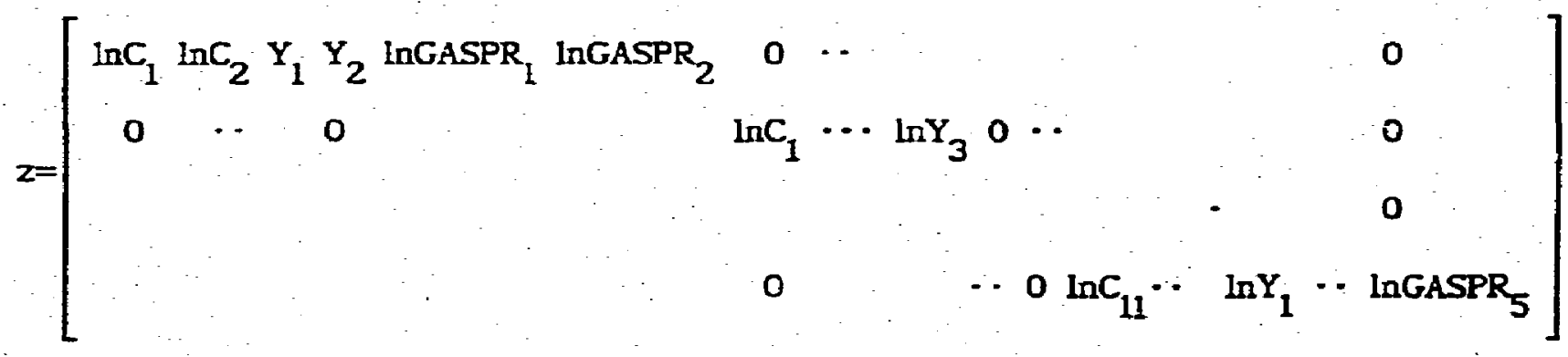

The error terms are assumed to be independently distributed across individuals, may be an MA process across time and can have an arbitrary form of heteroscedasticity.

We use a Generalized Method of Moments procedure to estimate the model. This consists of two steps, where in the second step we use the variance-covariance matrix that is estimated in the first step. For more detail, see Hansen (1982), Mackinnon and Davis (1993) and Arellano and Bond (1991). 


\section{Additional References}

Alarcon, Jorge G.G.R. 1986. "La Demanda de Transporte Urbano an el Area Metropolitana de la Ciudad de Mexico: Analisis Teorico y una Aplicacion Empirica al Caso de la Delegacion Alvaro Obregon." Ph.D. thesis, Instituto Tecnologico Autonomo de Mexico, Mexico, D.F.

Baltagi, Badi $H$. and James M. Griffin, (1983), "Gasoline Demand in the OECD: An Application of Pooling and Testing Procedures" European Economic Review, 22 pp. 117 137.

Berkowitz, Michael K., Nancy T. Gallini, Eric J. Miller and Robert A. Wolfe, (19??) "Disaggregate Analysis of the Demand for Gasoline". Canadian Journal of Economics

Bond, Eric W., (1983) "Trade in Used Equipment with Heterogeneous Firms" Journal of Political Economy, vol. 91, no. 4, pp689-705.

Carstens, Federico M. Carstens, and Ana Maria Escalante Mier. (1987). "Precios en el Sector Automotriz Mexicano 1974-86; Un Analisis Hedonico." Ph.D. thesis, Instituto Technologico Autonomo de Mexico, Mexico, D.F.

DeWitt, Diane E and Hadi Dowlatabadi, and Raymond J. Kopp. (1991). "Who Bears the Burden of Energy Taxes?" Discussion Paper QE91-12, Resources for the Future, Washington, D.C.

nllades, Ricardo W. (1989). "La Contaminación Atmosférica Producida por Fuentes Móviles en la Zona Metropolitana de la Ciudad de Mexico: Un Instrumento Eficiente de Control." Ph.D. thesis, Instituto Technologico Autonomo de Mexico, Mexico, D.F.

Rust, John, (1985) "Stationary Equilibrium in a Market for Durable Assets" Econometrica, rol 53, no. 4, pp $783-805$.

Sterner, Thomas, Carol Dahl and Mikael Franzen. (1992). "Gasoline Tax Policy, Carbon Emissions and the Global Environment". Journal of Iransport Economics and Policy, May. 


\section{Policy Research Working Paper Series}

Title

WPS1292 Services as a Major Source of Growth in Russia and Other Former Soviet States

Author

William Easterly

Miartha de Melo

Gur Oter

WPS1293 Product Standards. Imperfect Competition, and Completion of the Market in the European Union

Glenn Harrison

Thomas Rutherford

David Tarr

WPS1294 Regulations, Institutions, and Hadi Salehi Esfahani Economic Performance: The Political Cconomy of the Philippines' Telecommunications Sector

WPS1295. Why Higher Fiscal Spending Persists Bruno Boccara When a Boom in Primary Commodities Ends

WPS1296 Eamings-Related Mandatory Pensions: Concents for Design

Salvador Valdés-Prieto

Charles C. Guo

WPS1297 How Relative Prices Affect Fuel Use Pattems in Manufacturing: Plant-Level Evidence from Chile

James R. Tybout
Luis Serven

WPS1298 Capital Goods Imports, the Real Exchange Rate, and the Current Account

WPS1299 Fiscal Policy in Classical and Keynesian Open Economies

WPS1300 Dynamic Response to Extemal Shocks in Classical and Keynesian Economies

WPS1301 Estimating the Health Effects of Air Pollutants: A Method with an Application to Jakarta

WPS1302 Sustainability: Ethical Foundations and Economic Properties

Geir B. Asheim

Klaus Schmidt-Hebbel

Luis Serven

Klaus Schmidt-Hebbel

Luis Serven

Bant Ostro

Scott Barrett International Water Resources

WPS1304 Informal Gold Mining and Mercury Pollution in Brazil

WPS1305 information and Price Determination Nemat Shafik Under Mass Privatization
April 1994

April 1994

April 1994

April 1994

April 1994

May 1994

May 1994

May 1994

May 1994

Contact for paper

C. Rollison 84768

N. Artis

38010

B. Moore

35261

M. Pfeiffenberger 34963.

H. Rizkalla B4766

C. Jones 37699

E. Khine $3747 t$

E. Khine 37471

E. Khine 37471

C. Jones 37699

C. Jones 37699

C. Jones 37699

May 1994

D. Biller

37568

June 1994

A. Yideru 36067 
Policy Research Working Paper Series

Titie

WPS1306 Capital Flows and Long-Tem Equilibrium Real Exchange Rates in Chile

WPS1307 How Taxation Affects Foreign Direct Joosung Jun Investment (Country Specific Evidence)

WPS1308 Ownership and Corporate Conlrol in Poland: Why State Firms Defied the Odds

WPS1309 Is Demand for Polluting Goods Manageable? An Econometric Study of Car Ownership and Use in Mexico
Author

Ibrahim A. Elbadawi

Raimundo Soto

Brian Pinto

Sweder van Wijnbergen

Gunnar S. Eskeland

Tarhan N. Feyzioglu
Date

June 1994

June 1994

June 1994
Contact for paper

R. Martin 39065

S. King-Watson 31047

M. Kam-Cheong 39618

C. Jones

37699 
